\title{
Specific Detection of a Severe Strain of Sweet Potato Feathery Mottle Virus (SPFMV-S) by Reverse Transcription and Polymerase Chain Reaction (RT-PCR)
}

\author{
Masamichi NishiguCHI ${ }^{*,}$, Masaki MoRI ${ }^{*, \dagger}$, Fumihiko SuzUKI ${ }^{*, \dagger}$, Ryutaro NAGATA**, \\ Toshikazu MORISHITA*, Jun-ichi SAKAI*, Kaoru HANADA* \\ and Tomio USUGI***
}

Key words : $\quad$ sweet potato feathery mottle potyvirus, RT-PCR, SPFMV-severe strain, morning glory, Ipomoea nil.

Sweet potato feathery mottle virus (SPFMV), a member of the potyvirus group, is prevalent in sweet potato, Ipomoea batatas L. growing areas around the world ${ }^{7}$. Several strains of SPFMV have been reported in USA ${ }^{2,3}$ and Peru ${ }^{8)}$. In Japan, some strains of SPFMV have been isolated including the severe $(\mathrm{S})$, ordinary $(\mathrm{O})$, Tokushima (T) and F strains ${ }^{9-12)}$. SPFMV-S was found to be a causal agent of the 'Obizyo-sohi' disease of sweet potato, which occurs in southern parts of Japan ${ }^{12)}$. Consequently it is crucial to differently detect SPFMV-S strain from other strains which occur in Japan.

Molecular cloning and nucleotide sequence of the $3^{\prime}$ terminal region of the genomic RNA of SPFMV have already been reported in $\mathrm{USA}^{1)}$ for SPFMV-RC and -C strains. Mori et $a l^{5,6)}$ also reported the partial nucleotide sequence of SPFMV-O and -S genomes. These data make it possible to design strain-specific probes for the detection of SPFMV-S. Recently RT-PCR technique has been used for specific detection of virus strains ${ }^{13}$. In this paper we report the specific identification of SPFMV-S from infected morning glory, Ipomoea nil using the synthetic primers. The presence of possible inhibitors to the RT-PCR reaction in leaf extracts of sweet potato was also observed.

SPFMV-S and SPFMV-O were purified from infected leaves of morning glory, I. nil two weeks after inoculation as described previously ${ }^{10,12)}$. Viral RNA was prepared by slight modification of the method used by Cali and Moyer $^{2)}$. Here SPFMV-RNA was prepared by phenol extraction followed by ethanol precipitation instead of sucrose gradient ultra-centrifugation. cDNAs of SPFMV-S and $-\mathrm{O}$ were obtained as described previously ${ }^{5,6)}$.

Seeds of morning glory, I. nil L. cv. Scarlet O'Hara were sown and two weeks later the cotyledons which had been covered with carborundum (400 mesh) were inoculated with the respective strain of SPFMV using a glass spatula. Virus free sweet potato, I. batatas L. cv. Koukei no.24 was inoculated by grafting with infected morning glory.

Plant extracts for RT-PCR were prepared from virusinfected leaves. Frozen leaves (approximately $10 \mathrm{mg}$ ) were homogenized in a mortar and pestle with a mixture of $2 \mathrm{v} / \mathrm{w}$ of TE buffer (10 mM EDTA, 1\% 2-mercaptoethanol, $50 \mathrm{mM}$ Tris- $\mathrm{HCl}, \mathrm{pH} 8.0$ ) containing $1 \%$ cetyltrimethylammonium bromide and an equal volume of TE-saturated phenol. The resulting crude sap was collected into microcentrifuge tubes and centrifuged for 10 $\min$ at $15,000 \mathrm{rpm}$. The supernatant was mixed with an equal volume of chloroform and isoamylalcohol $(24: 1)$ and centrifuged for $5 \mathrm{~min}$ at $15,000 \mathrm{rpm}$. The supernatant was retained for the RT-PCR. In some cases, crude RNA was obtained from infected sweet potato leaf extracts by two ethanol precipitations of the supernatant. The final pellet was suspended in $20 \mu 1$ of TE. One $\mu 1$ of this solution was used for each RT-PCR reaction.

Two oligonucleotide primer sequences were designated from the alignment sequence data of the SPFMV-S genome $^{6}$, which is relatively heterologous to that of

* Kyushu National Agricultural Experiment Station, 2421 Suya, Nishigoushi, Kikuchi-gun, Kumamoto 861-11, Japan 九州農業試験場

** Miyazaki Prefectural Agricultural Experiment Station, Sadowara, Miyazaki, Miyazaki 880-02, Japan＼cjkstart宮崎県総合農 業試験場

*** Okinawa Branch, Japan International Research Center for Agricultural Sciences, 1091-1 Maeri, Ishigaki, Okinawa 907, Japan 国際農林水産業研究センター沖縄支所

+ Present address : National Institute of Agrobiological Resources, 2-1-2 Kan-nondai, Tsukuba, Ibaraki 305, Japan 現 在：農業生物資源研究所

${ }^{\dagger}$ Present address: National Institute of Agro-Environmental Sciences, 3-1-1 Kan-nondai, Tsukuba, Ibaraki 305, Japan 現在：農業環境技術研究所 


\section{S-CATCATATCAGAAA ATCTA TCATGGGTATTGGACCAAGCCCCATACAATGAATTAGCF

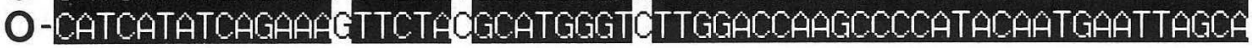

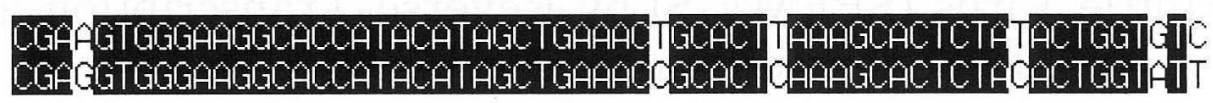

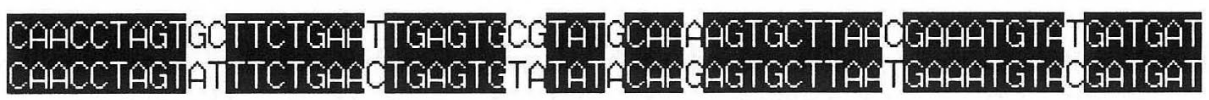

AGTGTACTTCFGGAGAATGAGTTAGAAGTATACCATCAATCTAGTGP-ACGTACTGAATT AGTATGCTTCA AGGAATGAGTTGGAAGTATA TCATCAATCTGGTGAGAAA-ACTGAATT

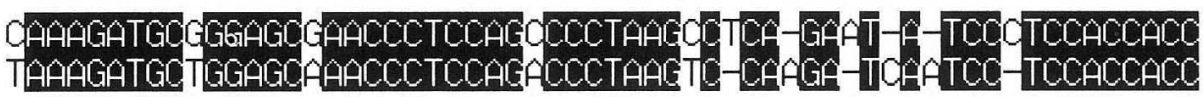

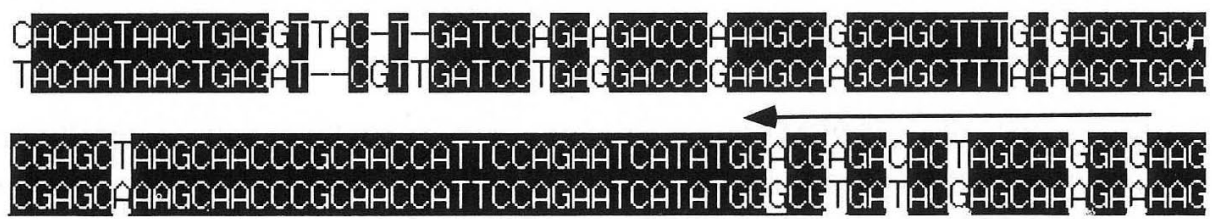

Fig. 1. Alignment of SPFMV-S ${ }^{6)}$ and $-\mathrm{O}^{5)}$ nucleotide sequences, corresponding to the 401 base-pair amplified DNA fragment. The two primer sequences corresponding to those of SPFMV-S were shown as arrows. Open and closed triangles show the location corresponding to the EcoRI recognition site and the processing site between nuclear inclusion $\mathrm{b}$ and coat protein, respectively.
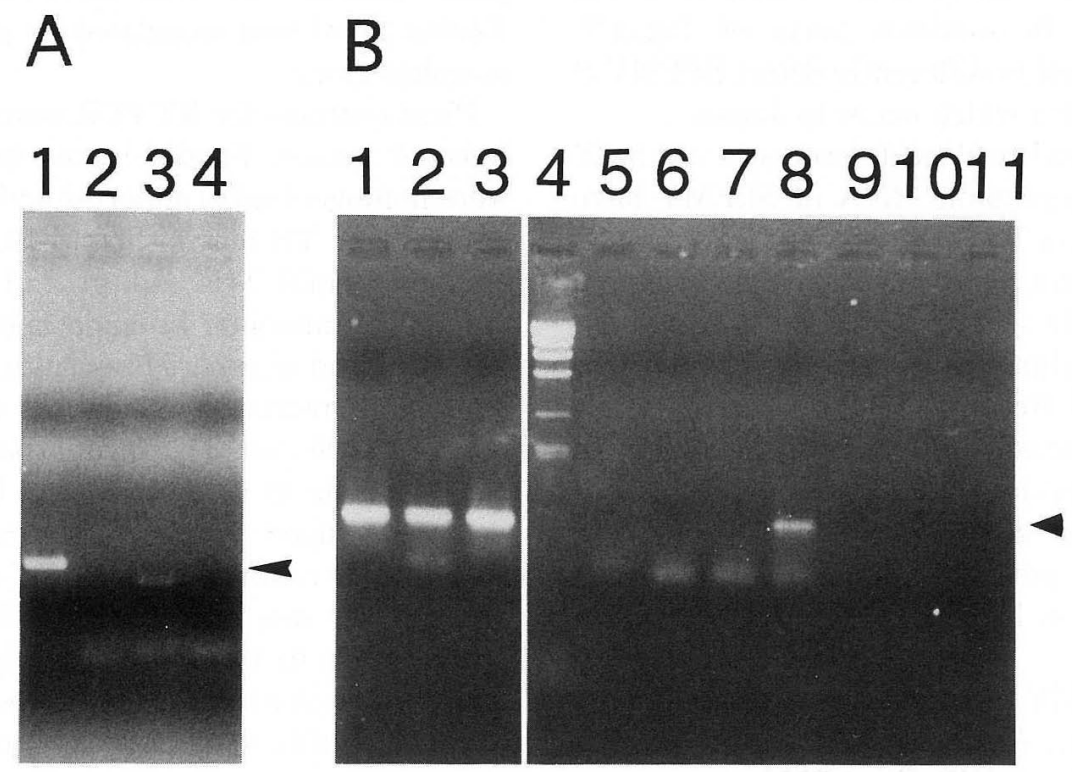

Fig. 2. Agarose gel electrophoresis of DNA fragments amplified from SPFMV RNA, cDNA and leaf extracts of virus infected morning glory, I. nil. The following templates were used in A: lane 1, SPFMV-S RNA (100 ng); lane 2, SPFMV-O RNA (100 ng); lane 3, control RNA (pAW transcript); lane 4, negative control (no DNA or RNA present in the reaction mixture) and in B: lane 1; SPFMV-S RNA (1 ng): lane 2; SPFMV-S RNA (0.01 ng): lane 3; SPFMV-S cDNA (0.1 ng): lane 4; molecular weight standard ( $\lambda /$ Hind III): lanes 5-8; healthy, SPFMV-T infected, SPFMV-O infected, and SPFMV-S infected leaf extract of $I$. nil, respectively: lane 9-11; healthy, SPFMV-O infected, and SPFMV-S infected leaf extracts of $I$. batatas, respectively. Arrows show the positions of the predicted DNA bands.

SPFMV-O ${ }^{5)}$ corresponding to the border sequences of nuclear inclusion b and coat protein genes (Fig. 1). Both primers (20 mer for each) were synthesized using a DNA synthesizer (ABI-PCR mate), containing $35-55 \% \mathrm{G}+\mathrm{C}$, resulting for the amplification of $401 \mathrm{bp}$ DNA fragment
(Fig. 1). These primers were used without any special purification.

RT-PCR was performed using GeneAmp ${ }^{\mathrm{TM}}$ RNA PCR kit (Takara) according to the manufacturer's protocol. To the reaction mixture $(19 \mu 1)$, one $\mu 1$ of the sample 
was added and first strand-cDNA synthesis was performed. The reaction mixture was then used for DNA amplification in $100 \mu 1$ reaction. The following thermal cycling scheme was used for 40 cycles (Perkin Elmer Cetus, GeneAmp ${ }^{\mathrm{TM}}$ PCR System): template denaturation at $95^{\circ} \mathrm{C}(1 \mathrm{~min})$ and primer annealing and DNA synthesis at $60^{\circ} \mathrm{C}(1 \mathrm{~min})$. The $10 \mu \mathrm{l}$ aliquot from each reaction mixture $(100 \mu 1)$ was analyzed by electrophoresis on $1 \%$ agarose gel in Tris-acetate EDTA buffer ${ }^{4}$. Gels were then stained with ethidium bromide.

Purified viral RNA or CDNA was used for RT-PCR or PCR, respectively. The amplified DNA fragments of expected size were obtained either from purified RNA or CDNA of SPFMV-S, whereas no DNA fragment was visible using purified RNA of SPFMV-O as template (Fig. 2-A). The negative control without viral RNA and positive control with pAW transcript were also performed (Fig. 2-A). These amplified DNA fragments carried the EcoRI recognition site at an expected location confirming that they were the correct PCR products (data not shown).

The same experiments were performed using samples from virus infected leaves of morning glory. DNA amplification was observed only when SPFMV-S infected leaf extracts were used but not when using SPFMV-O or SPFMV-T infected leaf extracts in the reaction mixture (Fig. 2-B). When samples were prepared from SPFMV-S, -O or - $\mathrm{T}$ infected and healthy leaves of sweet potato in the same way as that of morning glory, no amplified DNA fragment was observed (Fig. 2-B).

The crude RNA samples precipitated from supernatant of SPFMV-S infected sweet potato were subjected to RT-PCR. These RNA samples also failed to produce amplified DNA fragments. After a series of diluted solution of this crude RNA samples were added to each reaction mixture $(20 \mu 1)$ for the first strand cDNA synthesis in the presence of purified SPFMV-S RNA as template, no amplified DNA fragment was visible in the reaction mixture containing the aliquot of crude RNA sample diluted up to $10^{-2}$ (data not shown). However, the $10^{-3}$ diluted crude RNA sample did not cause inhibition in the production of the expected DNA fragment (data not shown). These results suggested that leaf extracts of sweet potato may contain some inhibitory compound(s) for RT-PCR. Thus, further sample preparation will be needed in the case of sweet potato. Filtration of the sample solution may improve the performance of the PCR reactions.

In conclusion, the synthesized primers which were derived from less homologous regions between SPFMV$\mathrm{S}$ and SPFMV-O could be used for the specific detection of SPFMV-S in infected leaf extract of morning glory but not in sweet potato under the conditions we used.

The numbers of mismatches in these primers were 3 of 20 bases (1.5\%) in the upstream and 6 of $20(3 \%)$ in the downstream primers. Generally mismatches of the $3^{\prime}$ termini of primers are important for specificity. We compared our PCR cycle scheme with the other one including template denaturation at $94^{\circ} \mathrm{C}(0.5 \mathrm{~min})$, primer annealing at $55^{\circ} \mathrm{C}(0.5 \mathrm{~min})$ and DNA synthesis at $72^{\circ} \mathrm{C}$ $(0.5 \mathrm{~min})$. The latter resulted in the production of nonspecific DNA bands. Amplification less than 35 cycles could not give clear DNA fragments.

The lack of amplified DNA products from SPFMV-T infected morning glory leaf extracts suggests that the sequences of SPFMV-T RNA at the same regions of the derived primers possibly differ from those of SPFMV-S.

The RT-PCR method can be used easily for detecting viral RNA sequences in morning glory leaves. From the practical point of view, however, it is important to apply this method to sweet potato. In the preparation of extracts from sweet potato, crude RNA precipitation by ethanol seems to cause problems, possibly due to polysaccharide. Further improvement in the preparation of the plant extracts will be required for the successive production of amplified DNA fragment by RT-PCR using sweet potato leaves.

The authors are grateful to Dr. Patricia Vazquez for correcting the English language of the manuscript.

\section{Literature cited}

1. Abad, J.A., Conkling, M.A. and Moyer, J.W. (1992). Comparison of the capsid protein cistron from serologically distinct strains of sweet potato feathery mottle virus (SPFMV) Arch. Virol. 126: 147-157.

2. Cali, B.B. and Moyer, J.W. (1981). Purification, serology and particle morphology of two russet crack strains of sweet potato feathery mottle virus. Phytopathology $71: 302-305$.

3. Hammond, J., Jordan, R.L., Larsen, R.C. and Moyer, J.W. (1992). Use of polyclonal antisera and monoclonal antibodies to examine serological relationships among three filamentous viruses of sweet potato. Phytopathology $82: 713-717$.

4. Maniatis, T., Fritsch, E.F. and Sambrook, J. (1982). Molecular Cloning, Cold Spring Harbor Laboratory, Cold Spring Harbor, New York, USA.

5. Mori, M., Sakai, J., Usugi, T., Hayashi, T. and Nishiguchi, M. (1994). Nucleotide sequence at the $3^{\prime}$ terminal region of sweet potato feathery mottle virus (ordinary strain, SPFMV-O) RNA. Biotech. Biosci., Biochem. 58 : 965-967.

6. Mori, M., Sakai, J., Kimura, T., Usugi, T., Hayashi, T., Hanada, K. and Nishiguchi, M. (1995). Nucleotide sequence analysis of two nuclear inclusion body and coat protein genes of a sweet potato feathery mottle virus severe strain (SPFMV-S) genomic RNA. Arch. Virol. (in press).

7. Moyer, J.W. and Salazar, L.F. (1989). Viruses and viruslike diseases of sweet potato. Plant Dis. 73 : 451455.

8. Nakashima, J.T., Salazar, L.F. and Wood, K.R. (1993). Sweet potato feathery mottle potyvirus $(\mathrm{Cl}$ isolate) virion and RNA purification. J. Virol. Meth. 44: 109116.

9. Onuki, M., Usugi, T., Nakano, M., Sakai, J. and Hanada, K. (1993). Sweet potato feathery mottle virus F strain isolated from sweet potato. Ann. Phytopathol. Soc. Jpn. 
59: 332 (Abstr. in Japanese).

10. Usugi, T., Nakano, M., Shinkai, A. and Hayashi, T. (1991). Three filamentous viruses isolated from sweet potato in Japan. Ann. Phytopathol. Soc. Jpn. 57 : 512521.

11. Usugi, T. and Maoka, T. (1993). Properties of sweet potato feathery mottle virus Tokushima strain (SPFMV-S). Ann. Phytopathol. Soc. Jpn. 59: 331-332 (Abstr. in Japanese).

12. Usugi, T., Nakano, M., Shinkai, A. and Hayashi, T. (1994). A distinct strain of sweet potato feathery mottle virus which causes obizyo-sohi disease on fleshy roots of sweet potato in Japan. Ann. Phytopathol. Soc. Jpn. $60: 545-554$.

13. Wetzel, T., Candresse, T., Ravelonandro, M. and Dunez, J. (1991). A polymerase chain reaction assay adapted to plum pox potyvirus detection. J. Virol. Meth. 33 : 355-365.

\section{和 文 摘 要}

西口正通・森 昌樹 - 鈴木文彦・長田龍太郎 - 森下敏和・酒井 淳一・花田 薰・宇杉富雄：RT-PCRによるサツマイモ斑紋モ ザイクウイルス強毒系統（SPFMV-S）の特異的検出

サツマイモ斑紋モザイクウイルスの強毒系統 (SPFMV-S) を 特異的に検出する RT-PCR 手法を検討した。SPFMVの 2 系 統, 強毒 $(\mathrm{S})$ 及び普通系統 $(\mathrm{O})$ の塩基配列をもとに, SPFMV-S 特異的プライマーを合成した。ウイルス RNA を鋳型にして, RT-PCR を行ったところ, SPFMV-S のRNA でのみ DNA 増 幅が観察された。同様に感染アサガオの磨砕液上清を供試した ところ, SPFMV-S 感染葉においてのみ DNA バンドが検出さ れたが, 感染サツマイモ葉の上清あるいは粗 RNA では検出さ れなかった。ウイルス RNA を含む反応液に粗 RNA の希釈液 を添加したところ，10 ${ }^{-2}$ 液では阻害され，10 $0^{-3}$ 液では阻害され なかった。このことはサツマイモには RT-PCR を阻害する物質 が含まれることを示唆する。

(Received August 24, 1994 ; Accepted November 28, 1994) 